Revista de Derecho Político, núm. 30, 1989, pp. 297-326

\title{
EL PODER JUDICIAL
}

\author{
(Reseña Bibliográfica)
}

POR

\author{
FERNANDO L. IBÁÑEZ LÓPEZ-POZAS \\ Profesor de Derecho Procesal
}

\section{JURISDICCION}

\section{En general}

OBRAS GENERALES

Almagro Nosete: Consideraciones de Derecho Procesal. Ed. Bosch. Barcelona 1988, págs. 9 y ss.

Almagro Nosete, Cortes Dominguez, Gimeno Senda y Moreno Catena: Derecho Procesal. Tomo I. Parte General. Proceso Civil (1). Tirant lo Blanch. Valencia 1987, págs. 43 y ss.

Aragoneses Alonso: Curso de Derecho Procesal Penal. Ed. Revista de Derecho Privado. Madrid 1986, págs. 77 y ss.

Calamandrel: Instituciones de Derecho Procesal Civil. Trad. Sentís Melendo. EJEA. Buenos Aires 1986. Tomo I, págs. 113 y ss.

Carnelutti: Derecho Procesal Civil y Penal. Trad. Sentís Melendo. EJEA. Buenos Aires 1971. Tomo I: Derecho y proceso. Tomo Il: Principios del Proceso Penal, págs. 62 y ss. 
Fenech Navarro: Derecho Procesal Penal. Ed. Labor. Barcelona-Madrid 1960. Tomo I, págs. 167 y ss.

Gomez Orbaneja y Herce Quemada: Derecho Procesal Civil. Madrid 1976, págs. 49 y ss.

Guasp Delgado: Derecho Procesal Civil. Instituto de Estudios Politicos. Madrid 1968. Tomo I, págs. 101 y ss.

laANez Frocham: La Jurisdicción. Ed. Astrea. Buenos Aires 1972, págs. 37 y ss.

Jiménez Asenjo: Derecho Procesal Penal. Ed. Revista de Derecho Privado. Tomo I, págs. 221 y ss.

Levene: Manual de Derecho Procesal Penal. Ed. OMEBA. Buenos Aires 1962, págs. 11 y ss., y 123 y ss.

Liegman: Manual de Derecho Procesal Civil. Trad. Sentis Melendo. EJEA. Buenos Aires 1980 , págs. 3 y ss.

Lorca Navarrete: Derecho Procesal Penal. Tecnos. Madrid 1986, págs. 19 y ss.

-: Derecho Procesal Orgánico. Tecnos. Madrid 1985, págs. 22 y ss.

Montero Aroca y Ortells Ramos: Derecho Jurisdiccional. Tomo I, Parte General. Ed. Bosch. Barcelona 1987, págs. 45 y ss.

Oliva Santos, de la y Fernandez: Derecho Procesal Civil. Tomo I: Introducción. El proceso civil, sus Tribunales y sus sujetos. Ed. PPU. Barcelona 1988, págs. 1 y ss.

Prieto-Castro y Ferrandiz: Derecho de Tribunales. Ed. Aranzadi. Pamplona 1986, págs. 83 y ss.

Paieto-Castro, Almagro Nosete y Gonzalez-Deleito: Tribunales Españoles. Organización y funcionamiento. Ed. Tecnos. Madrid 1979, págs. 135 y ss., y 144 y ss.

Ramos Méndez: Derecho Procesal Civil. Ed. Bosch. Barcelona 1986. Tomo I, págs. 51 y ss.

-: El Proceso Penal. Lectura Constitucional. Ed. Bosch. Barcelona 1988, págs. 17 y ss., y 69 y ss.

Viada López-Puigcerver y Aragoneses Alonso: Curso de Derecho Procesal Penal. Madrid 1974. Tomo l, págs. 57 y ss.

\section{MONOGRAFIAS}

AlcalA-Zamora y CASTillo: «Notas relativas al concepto de Jurisdicción”, en Estudios de teoria general e historia del proceso (1945-1972). México 1974. Universidad Nacional Autónoma. Tomo I, págs. 29 y ss., también en RDPI, 1972, pág. 447. 
BeCENA: Magistratura y Justicia, 1928.

Di lorio: «El concepto de Jurisdicción», en Temas de Derecho Procesal. Ed. Depalma. Buenos Aires 1985.

DOMINGo: «Jurisdicción y Judicación», en La Ley, núm. 2125, 20-12-88.

Falrén Guillen: Estudios de Derecho Procesal Civil, Penal y Constitucional. Ed. Revista de Derecho Privado. Madrid 1983.

GOMEZ OE LIANO: “La Jurisdicción», en Abogacia y Proceso. Oviedo 1988.

Montero Aroca: «Potestad, órgano y función jurisdiccionalw, en Trabajos de Derecho Procesal. Ed. Bosch, Barcelona 1988.

-: Introducción al Derecho Procesal: Jurisdicción, acción y proceso. Ed. Tecnos, Madrid 1979.

MuNoz Rojas: «Notas sobre la Jurisdicción y la acción en el ámbito del Proceso Penal», RDPI, núm. 1, págs. 171 y ss., 1977.

Ramos MÉndez: Derecho y Proceso. Ed. Bosch. Barcelona 1979.

\section{La unidad Jurisdiccional}

CAStro FILHO, DE: «Unidad de jurisdicción y justicia administrativa», RDPI, 1972, pág. 375.

Cazorla Prieto y Arnaldo alcubilla: aLos principios de unidad y exclusividad de la jurisdicción", en Temas de Derecho...

Fenech Navarro: Derecho Procesal Civil, págs. 19 y ss.

MONTERo ArocA: «La unidad jurisdiccional», en Trabajos de Derecho Procesal. Ed. Bosch. Barcelona 1988.

Montero Aroca y Ortells Ramos: Derecho Jurisdiccional. Tomo l, págs. 68 y ss.

Prieto-Castro y Ferrandiz: Derecho de Tribunales, págs. 83 y ss., y 147 y ss.

Prieto-Castro, Almagro y González-Deleito: Tribunales españoles..., págs. 157 y ss.

Ramos Méndez: Derecho Procesal Civil. Tomo I, págs. 158 y ss. 


\section{Garantías constitucionales de la Jurisdicción}

\section{A) Independencia}

\section{OBRAS GENERALES}

Almagro Nosete: Consideraciones de Derecho..., págs. 31 y ss.

Almagro Nosete, Cortes Dominguez, Gimeno Sendra y Moreno Catena: Derecho Procesal. Tomo I, págs. 57 y ss.

Calamandrel: Instituciones de Derecho... Tomo I, págs. 113 y ss.

Carnelutti: Derecho Procesal. Tomo I, págs. 81 y ss.

Devis Echandia: Principios fundamentales..., págs. 9 y ss.

Levene: Manual de Derecho..., págs. 197 y ss.

Liebman: Manual de Derecho..., págs. 3 y ss.

Lorca Navarrete: Derecho Procesal Orgánico, págs. 151 y ss.

Montero Aroca y Ortells Ramos: Derecho Jurisdiccional. Tomo I, págs. 124 y ss.

Oliva Santos, de la y Fernandez: Derecho Procesal... Tomo I, págs. 1 y ss.

Prieto-Castro: Derecho de los Tribunales, págs. 96 y ss., y 259 y ss.

Prieto-Castro, almagro y Gonzalez-Deleito: Tribunales españoles..., págs. 70 y ss.

Ramos Méndez: Derecho Procesal Civil. Tomo I, págs. 136 y ss.

-: El Proceso Penal..., págs. 70 y ss.

SAGües: Reforma Judicial. Ed. Astrea. Buenos Aires 1978, págs. 26 y ss. 


\section{MONOGRAFIAS}

Alvarez Gendin: La independencia del poder judicial. Madrid 1966.

Castan Tobenas: Poder Judicial e independencia judicial. Madrid 1951.

Cazorla Prieto y Arnaldo Alcubilla: «La sumisión del Juez a la ley y la independencia judicial», en Temas de Derecho..., págs. 323 y ss.

Dranguet: Responsabilidad e independencia del Poder Judicial. Madrid 1930.

Eyae Valera: «El arbitrio ministerial y la independencia judicial», en RD Privado, 1932, pág. 153.

Fairén Guiltén: Estudios de Derecho Procesal Civil, Penal y Constitucional. Madrid 1983.

Fuentes Pérez: «El principio de independencia judicial», RDJ, 1969, pág. 125.

JIMÉNEZ ASENJO: «La independencia de la justicia», RDPI, 1950, págs. 435.

LOPEZ y LOPEZ: «Independencia, imparcialidad y objetividad», en Problemas actuales de la Justicia. En Homenaje al Profesor Gutiérrez-Alviz y Armario. Valencia 1988.

MARINO, DE: «La independencia de los Tribunales, garantia de su función», RDP, núm. 2, pág. $431,1988$.

Sulva Melero: Las garantias de la independencia judicial. Ed. Reus. Madrid 1955.

SIMON: La independencia del juez. Ed. Ariel. Barcelona 1985.

Sото Nieto: Independencia del Poder Judicial: sus bases en la Ley Orgánica de 1870.

Martinez Calcerrada: «El principio de independencia de la función jurisdiccional», RGLJ, 1970, tomo I, pág. 846.

-: Independencia del Poder Judicial. Madrid 1970.

B) Inamovilidad

obRAS GENERALES

Almagro Nosete: Consideraciones de Derecho..., págs. 31 y ss.

Almagro nosete, Cortes dominguez, Gimeno Sendra y Moreno Catena: Derecho Procesal. Tomo I, págs. 57 y ss. 
Carnelutti: Derecho procesal... Tomo I, págs. 81 y ss.

Devis Echanola: Principios fundamentales..., págs. 9 y ss.

Gomez Orbaneja y Herce Quemada: Derecho Procesal Penal. Madrid 1984, págs. 51 y ss.

LeVene: Manual de Derecho..., págs. 197 y ss.

Montero aroca y Ortells Ramos: Derecho Jurisdiccional. Tomo I, págs. 119 y ss.

Oliva Santos, de la y Fernández: Derecho Procesal... Tomo I, págs. 1 y ss.

Prieto-Castro: Derecho de Tribunales, págs. 96 y ss., y 271 y ss.

Prieto-Castro, Almagro y Gonzalez-Deleito: Tribunales españoles..., págs. 73 y ss.

Ramos Méndez: Derecho Procesal Civil. Tomo I, págs. 136 y ss.

—: El Proceso Penal..., págs. 17 y ss., y 69 y ss.

MONOGRAFIAS

ReCCA: Inamovilidad de los Jueces, 1933.

SAInz MOREnO: «La inamovilidad judicial», REDA, 1976, pág. 653.

\section{C) Prohibiciones}

Almagro Nosete: Consideraciones de Derecho..., págs. 31 y ss.

almagro nosete, Cortes dominguez, Gimeno Sendra y Moreno Catena: Derecho Procesal. Tomo I, pág. 57 y ss.

LeVene: Manual de Derecho..., págs. 197 y ss.

Montero aroca y Ortells Ramos: Derecho Jurisdiccional. Tomo I, págs. 119 y ss.

Oliva Santos, de la y Fernandez: Derecho Procesal... Tomo I, págs. 1 y ss.

Prieto-Castro: Derecho de los Tribunales, págs. 96 y ss., y 259 y ss.

Prieto-Castro, Almagro y Gonzalez-Deleito: Tribunales españoles..., págs. 70 y ss. 
Ramos Méndez: Derecho Procesal Civil. Tomo I, págs. 115 y ss., y 136 y ss.

-: El Proceso Penal..., págs. 17 y ss., y 69 y ss.

\section{D) Responsabilidad}

\section{OBRAS GENERALES}

Almagro Nosete: Consideraciones de Derecho..., págs. 38 y ss.

Almagro Nosete, Cortés Dominguez, Gimeno Sendra y Moreno Catena: Derecho Procesal. Tomo I, págs. 57 y ss.

LeVene: Manual de Derecho..., págs. 197 y ss.

Lorca Navaraete: Derecho Procesal Orgánico, págs. 162 y ss.

Montero Aroca y Ortells Ramos: Derecho Jurisdiccional. Tomo I, págs. 131 y ss.

Oliva Santos, De la y Fernandez: Derecho Procesal... Tomo I, págs. 1 y ss.

Prieto-Castro: Derecho de los Tribunales, págs. 96 y ss., y 301 y ss.

Prieto-Castro, Almagro y Gonzalez-Deleito: Tribunales españoles..., págs. 80 y ss.

Ramos Méndez: Derecho Procesal Civil. Tomo I, págs. 141 y ss.

-: El Proceso Penal..., págs. 51 y ss.

\section{MONOGRAFIAS}

AGUILAR: «De la Responsabilidad Judicial», RGLJ, 1984, tomos I y II, págs. 479 y 491 (respectivamente).

Almagro Nosete: «Problemática del "recurso" de responsabilidad civil contra Jueces y Magistrados», RDPI, 1971, pág. 291.

—: Responsabilidad Judicial. Ed. El Almendro. Córdoba 1984.

CAPEllett: La responsabilidad de los Jueces. Ed. JUS. La Plata (Argentina) 1988. 
Cazorla Prieto y Arnaldo alcubilla: «La responsabilidad penal, civil y disciplinaria de los Jueces", en Temas de Derecho..., págs. 447 y ss.

-: "La responsabilidad del Estado-Juez", en Temas de Derecho..., págs. 429 y ss.

Comas: Proposición de la Ley sobre Responsabilidad Judicial, 1890.

Dranguet: Responsabilidad de independencia del Poder Judicial. Madrid 1930.

Escusol Barra: «Responsabilidad de Jueces y Magistrados en el ejercicio de sus funciones", en Estudios sobre la Ley Orgánica del Poder Judicial. Colex. Madrid 1989, págs. 193 y ss.

Fernandez Hierro: Responsabilidad Civil Judicial. Ed. Aranzadi. Pamplona 1987.

GABALDON LOPEZ: «Responsabilidad disciplinaria de Jueces y Magistrados», en Sistema Judicial español: Poder Judicial, mandatos constitucionales y politica Judicial. Rev. Poder Judicial, número especial, V, págs. 133 y ss.

Garcla Manzano: «Responsabilidad del Estado por funcionamiento anormal de la Administración de Justicia», en Sistema Judicial español..., Rev. Poder Judicial, número especial $\mathrm{V}$, págs. 177 y ss.

Garcia San Miguel: «La Responsabilidad Judicial», RGLJ, 1901, pág. 262.

LOPEZ DE HARO: «La responsabilidad Judicial». RGLJ, 1918, tomos 1 y 2, págs. 404 y 75 y 441 (respectivamente).

Martin Rebollo: Jueces y Responsabilidad del Estado. Centro de Estudios Constitucionales. Madrid 1983.

Montero Aroca: Responsabilidad Civil del Juez y del Estado por la actuación del Poder Judicial. Ed. Tecnos. Madrid 1988.

MANRESA: «Los recursos de responsabilidad contra Jueces y Magistrados", $R G L J, 1885$, tomo II, pág. 577.

Movilla Álvarez: «Notas sobre la responsabilidad de Jueces y Magistrados», Justicia 88, núm. II.

-: «Responsabilidad del Juez», en Sistema Judicial español..., Rev. Judicial, número especial V, págs. 159 y ss.

Rodriguez AliQUe: «Algunas reflexiones sobre la responsabilidad civil de Jueces y Magistrados», Justicia 88, núm. III, pág. 613.

RuIZ VADILLO: «Responsabilidad de Jueces y Magistrados: civil, penal y disciplinaria», en Sistema Judicial español..., Rev. Poder Judicial, número especial V, págs. 115 y ss. 


\section{E) Sumisión}

\section{OBRAS GENERALES}

Almagro Nosete: Consideraciones de Derecho..., págs. 9 y ss.

Almagro nosete, Cortés Dominguez, Gimeno Sendra y Moreno Catena: Derecho Procesal. Tomo I, págs. 57 y ss.

Fenech Navarro: Derecho Procesal Penal. Tomo I, págs. 167 y ss.

Gomez Orbaneja-Herce Quemada: Derecho Procesal Civil, págs. 49 y ss.

Guasp Delgado: Derecho Procesal Civil. Tomo I, págs. 101 y ss.

Jiménez Asenjo: Derecho Procesal Penal. Tomo l, págs. 221 y ss.

LeVene: Manual de Derecho..., págs. 197 y ss.

Lorca NavarRete: Derecho Procesal Orgánico, págs. 22 y s.

Montero Aroca y Ortells Ramos: Derecho Jurisdiccional. Tomo I, págs. 136 y ss.

Oliva Santos de la, y Fernández: Derecho Procesal... Tomo I, págs. 1 y ss.

Prieto-Castro: Derecho de Tribunales, págs. 96 y ss., y 259 y ss.

Prieto-Castro, Almagro y Gonzalez-Deleito: Tribunales españoles..., págs. 135 y ss., y 144 y ss.

MONOGRAFIAS

Cazorla Prieto y Arnaldo alcubilla: "La sumisión del Juez a la ley y la independencia judicial», en Temas de Derecho..., págs. 323 y ss.

\section{La fe pública judicial}

Almagro Nosete, Cortés Dominguez, Gimeno Sendra y Moreno Catena: Derecho Procesal. Tomo I, págs. 75 y ss. 
Fenech Navarro: Derecho Procesal Penal. Tomo I, págs. 167 y ss.

Prieto-Castro: Derecho de Tribunales, págs. 83 y ss.

Prieto-Castro, Almagro y González-Deleito: Tribunales españoles..., págs. 83 y ss., 135 y ss., y 144 y ss.

TOME PAULE: La fe pública judicial y las funciones del secretario en la nueva Ley Orgánica del Poder Judicial. Madrid 1985.

\section{El Gobierno del Poder Judicial}

\section{OBRAS GENERALES}

Almagro Nosete: Consideraciones de Derecho..., pags. 39 y ss., y 45 y ss.

Almagro Nosete, Cortes Dominguez, Gimeno Sendra y Moreno Catena: Derecho Procesal. Tomo I, págs. 81 y ss.

Fenech Navarro: Derecho Procesal Penal. Tomo I, págs. 167 y ss.

Lorca Navarrete: Derecho Procesal orgánico.

Montero Aroca y Ortells Ramos: Derecho Jurisdiccional. Tomo I, págs. 256 y ss.

Prieto-Castro: Derecho de Tribunales, págs. 391 y ss., y 402 y ss.

Ramos Mendez: Derecho Procesal Civil. Tomo I, págs. 85 y ss., y 117 y ss.

\section{MONOGRAFIAS}

Cacho Frago, Del: "Gobierno interno de Tribunales y Juzgados. Salas de Gobierno. Presidentes de Tribunales Superiores de Justicia. Junta de Jueces», en Sistema Judicial español..., Rev. Poder Judicial, número especial V, pág. 219.

Cazorla Prieto y Arnaldo Alcubilla: El Consejo General del Poder Judicial como órgano constitucional, pág. 365.

-: «El Gobierno interno de los Juzgados y Tribunales. La carrera Judicial», en Temas de Derecho..., pág. 385. 
GutierRez de CABIEDES: «Observaciones al tema del autogobierno de la Magistratura», en Estudios de Derecho..., pág. 109.

Prieto-Castro: «El autogobierno de la Magistratura», RDPI, 1970, tomo II, pág. 251.

TORNE GARClA: «Autogobierno de la Magistratura», RJCat., 1974, pág. 519.

VACAs GaRcia-Alos y Tenorio SÁnChez: «Reflexión sobre el organo de control de los acuerdos del Consejo General del Poder Judicial", La Ley, núm. 1960, 3-5-88.

VARIOS Autores: «El autogobierno de la Magistratura», en Materiales de la VI Reunión anual de Profesores de Derecho Procesal de las Universidades españolas. Madrid 1970.

\section{ORGANIZACIÓN DE LOS TRIBUNALES}

\section{OBRAS GENERALES}

Almagro Nosete: Consideraciones de Derecho..., págs. 77 y ss.

Almagro Nosete, Cortes Dominguez, Gimeno Sendra y Moreno Catena: Derecho Procesal. Tomo I, págs. 87 y ss.

Aragoneses Alonso: Curso de Derecho..., págs. 91 y ss.

Calamandrel: Instituciones de Derecho... Tomo Il, págs. 19 y ss.

Fenech Navarro: Derecho Procesal Penal. Tomo I, págs. 139 y ss.

Gomez de Liano GonzAlez: El Proceso..., págs. 49 y ss.

Guasp Delgado: Derecho Procesal Civil. Tomo I, págs. 120 y ss.

LeVene: Manual de Derecho Procesal Penal, págs. 175 y ss.

Lorca Navarrete: Derecho Procesal Orgánico, págs. 103 y ss.

Montero Aroca y Ortells Ramos: Derecho Jurisdiccional. Tomo l, págs. 119 y ss., y 157 y ss. Montón Redondo: Juzgados y Tribunales españoles. Madrid 1986.

Moreno Catena, Almagro Nosete, Cortes Dominguez y Gimeno Sendra: El nuevo Proceso Penal. págs. 21 y ss. 
Oliva Santos, de la y Fernandez: Derecho Procesal Civil. Tomo I, págs. 13 y ss.

Prieto-Castro, Almagro nosete y González-Deleito: Tribunales españoles..., págs. 83 y ss.

Prieto-Castro: Derecho de Tribunales. Ed. Aranzadi, Pamplona 1986.

Ramos MÉndez: Derecho Procesal Civil. Tomo I, págs. 11, 29 y ss., 58 y ss., y 70 y ss.

一: El Proceso penal..., págs. 89 y ss.

SAGÜÉs: Reforma Judicial.

Viada lópez-Puigcerver y Aragoneses Alonso: Curso de Derecho... Tomo I, págs. 77 y ss.

\section{MONOGRAFIAS}

Alcala-Zamora y Castillo: "Jerarquía de los Tribunales Supremos", en Ensayos de Derecho Procesal, pág. 609.

ALFOnso PINAZO, DE: «La competencia transitoria de las Audiencias Territoriales para conocer de las causas penales seguidas contra aforados autónomos», BIMJ, núm. 1487 (5-4-88).

ALONSO OLEA: «Nota sobre el orden jurisdiccional social en la transición entre plantas», REDT, núm. 37, pág. 37 (enero-marzo), 1989.

Almagro Nosete: "El Poder Judicial», en Problemas actuales de la Justicia. Homenaje al Prof. Gutiérrez Alviz y Armario. Valencia 1988.

Andrés lbanez: El Poder Judicial. Tecnos. Madrid 1986.

Barona VILLAR: «EI Tribunal de Justicia de las Comunidades Europeas», RGD, núm. 523, abril de 1988.

CARPI PéreZ, DE: «Algunos aspectos de la actividad jurisdiccional del Tribunal Constitucional», La Ley, núm. 2178, pág. 1, 3-3-89.

Conde MARTIN de HiJAS: "Comentario urgente sobre la Ley de Demarcación y Planta Judicial. En relación con los órganos del orden social de la jurisdicción», Actualidad Laboral, núms. 10 y 11, 1989, págs. 109, 127.

FAIRÉn GuILLEN: «Para una reforma de las Leyes de Tribunales y Procesales», BICAM, núm. 4, pág. 23, julio-agosto de 1988.

-: «El Tribunal de las aguas de Valencia y las sanciones previstas por la Ley de aguas de 1985 y su Reglamento: inaplicabilidad de sus normas", REDA, núm. 57, enero-marzo de 1988. 
Fernandez Alvarez: «La Administración de Justicia en Aragón: el Tribunal Superior de Justicia”, BIMJ, núm. 1493, 5-6-88.

GOMEz del CASTILLO: «Notas sobre los principios político-constitucionales que informan la organización y funcionamiento de los Tribunales», en Problemas Actuales de la Justicia.

González Pérez: “La ley de Planta y el proceso administrativo", REDA, núm. 61, pág. 19, enero-marzo de 1989.

Herce Quemada: «La nueva justicia municipal», RDP, 1946, pág. 47.

LópZZ-MuÑIz GoÑı: La demarcación judicial. Madrid 1967.

Martín Ostos: «Los futuros Juzgados de Menores», en Problemas actuales de la Justicia.

-: «Los Juzgados de Menores en la nueva organización judicial», Justicia 88, núm. IV, pág. 859.

—: "La ruleta de la Justicia», Justicia 88, núm. III, pág. 533.

MARTINEz EMPERADOR: “Los nuevos órganos jurisdiccionales del orden social», Actualidad Laboral, núm. 15, pág. 183, 1989.

Morenilla Rodriguez: "La reforma Judicial y la Ley de Bases Orgánica de la Justicia», RDPI, núm. I, pág. 151, 1977.

Navarro Hernan: «Reflexiones sobre el estado de la Administración de Justicia», BICAM, núm. 5, pág. 49, septiembre-octubre de 1988.

Oliva SANTOS, DE LA: «Nuevo panorama de la Administración de Justicia según la Ley Orgánica del Poder Judicial», en Problemas Actuales de la Justicia.

-: «Competencia, reparto, cambio de Tribunal y derecho al Juez predeterminado por la Ley", BICAM, núm. 2, marzo-abril de 1989.

ORtells Ramos: «La competencia judicial en la Ley de Reforma de la adopción», Justicia 88, núm. IV, pág. 835.

Otto y PARDO: «Los Tribunales Superiores de Justicia», BIMJ, núm. 1471, 15-10-87.

REQUero lbaNez: «La nueva organización de los órganos de la jurisdicción contencioso-administrativa. Algunas notas sobre el Proyecto de Ley de Demarcación y Planta Judicial», Actualidad Administrativa, núm. 38, 1988.

Reyes Monterreal: «La Administración de Justicia», B/CAM, núm. 5, pág. 33, septiembre-octubre de 1988.

Rodriguez Aguilera: «La reforma de la organización judicial española». 
Rodriguez Castro: “Los Jueces de Paz: sus funciones en el Registro Civil», Actualidad Civil, núm. 23, 5-6-89.

Rodriguez del Barco: Compendio de Derecho Judicial. Organización de los Tribunales. Madrid 1962.

RuIz JaRABo: «Homenaje a una Ley centenaria (la Ley Orgánica del Poder Judicial de 15 de septiembre de 1870)", RGLJ, tomo II, pág. 359, 1970.

-: "La Administración de Justicia en la sociedad española de nuestro tiempo", RGLJ, tomo II, pág. 471, 1971.

RulL: Problemas orgánicos de la Administración de Justicia. Madrid 1955.

SERRA DOMINGUEZ: «Notas esquemáticas sobre la distribución y composición de los Tribunales», RDPI, 1972, pág. 695.

Serrera Contreras: «La Audiencia Territorial de Sevilla y la Ley Orgánica del Poder Judicial», en Problemas actuales de la Justicia.

VALDÉS DAL-RE: «Competencia funcional de los órganos de nueva planta y del orden jurisdiccional social», Actualidad Laboral, núm. 29, pág. 1649, 1988.

Valls Gombau: «Las competencias penales de los Tribunales Superiores de Justicia», Poder Judicial, núm. 13, pág. 57, marzo de 1989.

-: «El Tribunal de Cassació de Catalunya», RJCat., núm. 3, pág. 593, 1988.

-: "Las competencias civiles de los Tribunales Superiores de Justicia", Justicia 88, núm. II, pág. 329.

-: : «os Tribunales Superiores de Justicia en las Comunidades Autónomas según la Constitución", $R G D$, núm. 524, pág. 2521, mayo de 1988.

VEGA BENAYAS, DE LA: Introducción al Derecho Judicial. Madrid 1970.

VILLAGOMEZ RODIL: «Competencias de los órganos judiciales penales en la nueva organización judicial», Actualidad Penal, núm. 9, pág. 437, 1989.

\section{PERSONAL DE LOS ÓRGANOS JURISDICCIONALES}

\section{OBRAS GENERALES}

Almagro Nosete: Consideraciones de Derecho..., págs. 80 y ss.

Almagro Nosete, Cortés dominguez, Gimeno Sendra y Moreno Catena: Derecho Procesal. Tomo I, págs. 107 y ss. 
ARAgoneses Alonso: Curso de Derecho..., págs. 107 y ss.

Calamandrei: Instituciones de Derecho... Tomo II, págs. 23 y ss., y 261 y ss.

CARnelutTI: "De la educación de los Jueces y de los Abogados penales", en Cuestiones sobre el Proceso Penal. Trad. Sentis Melendo. EJEA. Buenos Aires 1961, págs. 187 y ss.

Fenech Navarro: Derecho Procesal Penal. Tomo l, págs. 139 y ss.

Gomez de Liaño GonzAlez: EI Proceso..., págs. 53 y ss.

Guasp Delgado: Derecho Procesal Civil. Tomo I, págs. 142 y ss.

Lorca NavarRete: Derecho Procesal Orgánico, págs. 131 y ss., y 177 y ss.

Montero Aroca y Ortells Ramos: Derecho Jurisdiccional. Tomo I, págs. 186 y ss., y 219 y ss.

Prieto-Castro: Derecho de Tribunales, págs. 339 y ss.

Prieto-Castro, Almagro y Gonzalez-Deleito: Tribunales españoles..., págs. 62 y ss.

Ramos Mendez: Derecho Procesal Civil. Tomo I, págs. 30 y ss., 110 y ss., y 132 y ss.

Viada Lopez-Puigcerver y Aragoneses Alonso: Curso de Derecho, págs. 95 y ss.

MONOGRAFIAS

Agullar: "Cuestiones de Derecho Judicial», RDPriv., 1925, pág. 271.

Álvarez-Castellanos: «Presente y futuro del Secretario Judicial», RDP, 1947, pág. 183.

Alvarez VALDES: «Función del secretario judicial según la vigente legalidad», RGLJ, 1930, pág. 329.

ANDRÉS IBAÑEz: «El Juez del Título Preliminar (la justicia del "Éstado de Derecho" es la crisis del "Éstado Social")", Justicia 88, núm. I.

AunOS: «El proceso y el Secretario Judicial», RDP, 1945, pág. 9.

Diaz SuÁrez: “Los Jueces ante la crisis de la Justicia», RGD, núm. 523, abril de 1988.

DOMINGUez MORENO: “El secretario judicial en la nueva organización de Justicia», RDPI, 1976, pág. 423. 
Garcia Paredes: “Oficina judicial. Alternativas. Informatización. Nuevas tecnologias. Política funcionarial”, en Sistema Judicial español..., Rev. Poder Judicial, número especial V, pags. 207 y ss.

GARClA VALDÉs: «El secretario judicial en el futuro esquema del Centro de Estudios Judiciales», $B I M J$, núm. 1490, 5-5-88.

-: «El sistema de acceso a la judicatura y la selección de jueces en España», BIMJ, núm. 1512, 15-12-88, pág. 539.

Gonzalez-CuÉlar Garcia: "Formación y perfeccionamiento de Jueces y Magistrados”, en Sistema judicial español, Rev. Poder Judicial, número especial V, pág. 87.

Herce Quemada: El secretario judicial. Madrid 1949.

-: «El problema fundamental del secretario judicial», RDJ, 1964 (18), pág. 127.

Huertas Contreras y Ruiz-Rico: «Jueces, Poder Judicial y Administración de Justicia en España”, Documentación Juridica, núm. 53, pág. 23, enero-marzo de 1987.

Huertas Contreras y Vera Padial: «Secretarios judiciales, Poder Judicial y Administración de Justicia en España”, Documentación Jurídica, núm. 53, pág. 141, enero-marzo de 1987.

LoRCa NAvarrete: “Los Secretarios judiciales y el artículo 35.3 del Estatuto de Autonomia Vasco", Rev. Vasca de Derecho Procesal y Arbitraje, núm. 1, pág. 22, 1989.

Onecha Santamaria: "Condiciones personales para el ejercicio de la función judicial», RDJ, 1967 (31), pág. 53.

-: «Factores humanos en la función de juzgar», RDJ, 1968 (38), págs. 23.

Ossorio: «El secretario judicial», RGLJ, 1911, pág. 145.

Pedraz Penalva: «Sobre el carácter de autoridad del sećretario judicial en la Ley orgánica del Poder Judicial», en Problemas actuales..., págs. 293.

Prieto-Castro: «Agentes judiciales y eficacia del Derecho», RDP, 1950, pág. 725.

Ramos Gavilan: "La Ley Orgánica del Poder Judicial y el Secretario de la Administración de Justician, RGD, núm. 519, diciembre de 1987.

RAmos GonzAlez: «El secretario judicial en la nueva Ley Orgánica de la Justicia», RDPI, 1976, págs. 945.

SANCHEZ GuiSANDO: «Colaboradores del Juez», $R T$, 1933, pág. 7.

SANCHEz Rivera: «El Poder Judicial y los representantes de la Administración de Justicia», $R T$, 1932, págs. 140. 
SeOANe CACHARron: “El secretario judicial y las garantías constitucionales del derecho a un proceso debido", RDP, núm. 1, 1988.

Soto VAzquez: «El Juez de lo criminal», RDP, 1967. Tomo III, pág. 109.

TOME PAULE: La fe pública judicial y las funciones del secretario en la nueva Ley Orgánica del Poder Judicial. Madrid 1985.

VIADA: «Notas sobre el Proyecto de Ley de organización del secretariado y auxiliares de la administración de justicia», RGLJ, 1947, pág. 324.

\section{JURISDICCIÓN MILITAR}

\section{OBRAS GENERALES}

Gimeno Sendra, Moreno Catena, Almagro Nosete y Cortés Dominguez: Derecho Procesal. Tomo II. El Proceso Penal. Valencia 1988, págs. 737 y ss.

Prieto-Castro y Gutierrez de Cabiedes: Derecho Procesal Penal. Madrid 1987, págs. 41 y ss., y 58 y ss.

\section{MONOGRAFIAS}

CASAdo Burbano: Iniciación al Derecho Constitucional Militar. Madrid 1986. EDERSA.

Chavarri Zapatero: Régimen disciplinario militar. 1986.

FAIRÉN GUILLÉN: «Notas sobre Jurisdicciones especiales», RDPI, 1971, Madrid.

FernANdez SEgAdo: «La Jurisdicción Militar en nuestro ordenamiento constitucional (la problemática del art. 1117.5 de nuestra Constitución)", RDP, núms. 88 y $89,1982$.

Gallego: «La nueva organización de la Justicia Militar», RGD, núm. 502, mayo de 1987.

Gómez del CAstlllo: El fundamento y la extensión de la Jurisdicción Militar, 1972.

-: «La extensión de la Jurisdicción militar en el Derecho comparado", RDPI, pág. 349, Madrid 1975. 
Laudin Carrasco: Manual de Derecho Penal y procedimientos militares. Ministerio de Marina, Madrid 1967.

LOPEZ RAMON: La caracterización juridica de las Fuerzas Armadas. Centro de Estudios Constitucionales, Madrid 1987.

Portero Garcia: «La Jurisdicción Militar», RGD, 1968, págs. 194 a 290.

SAHIR ERMAN: «Evolución actual de las jurisdicciones militares», REDM, núm. 35, 1978.

Valenciano Almorna: «En torno a un nuevo Código de Justicia Militar”, REDM, núm. 35, 1978.

Varios Autores: Comentarios al Codigo Penal Militar. Civitas, S. A., Madrid 1988.

VENTRO: «La independencia en la Justicia Militar», REDM, núm. 37, 1979.

\section{ORGANOS PROMOTORES DE LA JUSTICIA}

\section{Ministerio Fiscal}

\section{OBRAS GENERALES}

Almagro Nosete, Cortes Dominguez, Gimeno Sendra y Moreno Catena: Derecho Procesal. Tomo I. Parte General. Proceso Civil (1), Valencia 1988, págs. 171 y ss., y 318 y ss.

-: Derecho Procesal. Tomo II. Proceso Penal. Valencia 1988, págs. 141 y ss.

Aragoneses Alonso: Instituciones de Derecho Procesal Penal, págs. 121 y ss.

-: «Curso de Derecho Procesal Penal», Rev. de Derecho Privado. Madrid 1986, págs. 115 y ss.

Calamandrei: Instituciones de Derecho Procesal Civil. Trad. Sentís Melendo. EJEA. Buenos Aires 1986. Tomo II, págs. 425 y ss.

Carnelutti: Derecho Procesal Civil y Penal. Trad. S. Sentis Melendo. EJEA. Buenos Aires 1971. Tomo I: Derecho y Proceso, págs. 117 y ss. Tomo Il: Principios del Proceso Penal, págs. 36 y ss.

Fenech Navarro: Derecho Procesal Penal. Ed. Labor. Barcelona-Madrid 1960. Tomo I, págs. 309 y ss. 
Gomez de Liaño: El Proceso Penal, págs. 65 y ss.

Gomez Orbaneja y Herce Quemada: Derecho Procesal Penal. Madrid 1987, págs. 70 y ss.

Guasp Delgado: Derecho Procesal Civil. Instituto de Estudios Politicos. Madrid 1968. Tomo I, págs. 162 y ss.

Jiménez Asenjo: Derecho Procesal Penal. Ed. Revista de Derecho Privado. Madrid, s/t. Tomo I, págs. 144 y ss.

Lorca Navarrete: Derecho Procesal Penal. Tecnos, Madrid 1986, págs. 65 y ss.

-: Derecho Procesal Orgánico. Tecnos. Madrid 1985, págs. 197 y ss.

Moreno Catena, Almagro Nosete, Cortés Dominguez y Gimeno Sendra: El nuevo Proceso Penal. Valencia 1989, págs. 65 y ss.

Montero Aroca y Ortells Ramos: Derecho Jurisdiccional. Tomo I. Parte General. Ed. Bosch. Barcelona 1987, págs. 239 y ss.

Prieto-Castro: Derecho de Tribunales. Ed. Aranzadi. Pamplona 1986, págs. 473 y ss.

Prieto-Castro, almagro Nosete y Gonzalez-Deleito: Tribunales españoles. Organización y funcionamiento. Tecnos. Madrid 1979, págs. 87 y ss.

Prieto-Castro y Gutiérrez de Cabiedes: Derecho Procesal Penal. Tecnos, Madrid 1987, págs. 113 y ss.

Ramos Méndez: Derecho Procesal Civil. Ed. Bosch. Barcelona 1986. Tomo I, págs. 30, 119 y ss.

-: El Proceso Penal. Lectura constitucional. Ed. Bosch. Barcelona 1988, págs. 122 y ss.

Viada Lopez-Puigcerver y Aragoneses Alonso: Curso de Derecho Procesal Penal. Madrid 1974. Tomo I, págs. 105 y ss.

\section{MONOGRAFIAS}

alcala-Zamora y Castillo: “Lo que debe ser el Ministerio Público», en Estudios de Derecho Procesal. Madrid 1934, pág. 1.

Calvo Rublo: «El Ministerio Fiscal en la Constitución», Poder Judicial I, pág. 623.

CAMAÑo: «El Ministerio Público y Fiscal», RDPArg., 1950, pág. 167.

Carnelutti: Cuestiones sobre el Proceso Penal. Trad. Sentís Melendo. EJEA. Buenos Aires 1961, págs. 209 y ss. 
CEREzo ABAD: “El fiscal como defensor del interés social», RGLJ, 1965, I, págs. 62 y ss.

CONDE-PUMPIDO: “La naturaleza y principios rectores del Ministerio Fiscal en la Constitución y el nuevo Estatuto orgánico", Poder Judicial l, pág. 843.

CONDE PUMPIDO y otros: “El Ministerio Fiscal como defensor de la legalidad y de los intereses públicos", Primeras Jornadas de Derecho Judicial, pág. 697.

Falrén: «La situación actual del Ministerio Fiscal», Rev. de Derecho Procesal, 1970, pág. 759.

-: «El papel del Ministerio Fiscal español en el proceso civil», Rev. General de Legislación y Jurisprudencia, 1974, pág. 655.

Fernandez-Martin Granizo: El Ministerio Fiscal en España, 1977.

GIL-Albert: «El Ministerio Fiscal en la Constitución», Poder Judicial l, pág. 105.

Gomez Orbaneja: «La irrecusabilidad del Ministerio Fiscal», Rev. de Derecho Procesal, 1946, pág. 601.

IBANẼE: «Independencia y autonomia del Ministerio Fiscal en el Proceso Penal», Rev. Derecho Procesal, 1967, II, pág. 103.

JimenEZ BLANCO: «Relevancia constitucional del Ministerio Fiscal», Poder Judicial II, pág. 1261.

Lopez Serrano: «El Ministerio Público», Rev. General de Legislación y Jurisprudencia, 1880, pág. 285.

LORCA GarCIA: «El Ministerio Fiscal en la Constitución», Rev. General de Derecho, 1982, núm. 456, pág. 1314.

Martín PaLLIN: “El Ministerio Fiscal en la busca de la legalidad y de los intereses generales», Poder Judicial II, pág. 1787.

Martinez la Fuente: «La Posición del Ministerio Fiscal en el proceso penal», Rev. General de Legislación y Jurisprudencia, 1922, pág. 245.

MIGUel y ALONSO: “El Ministerio Fiscal. Magistratura de amparo», Rev. Derecho Procesal, 1954, pág. 537.

-: “El fiscal en el proceso penal», Actas del I Congreso Nacional de Derecho Procesal, 1950, pág. 177.

Moral GARClA: «La intervención del Ministerio Fiscal en los procesos por calumnias o injurias con publicidad contra particulares", Rev. Poder Judicial, núm. 7, 1987, pág. 9.

Munoz CALvo: «La independencia del Ministerio Fiscal en España, su problemática. El llamado Consejo Fiscal", Poder Judicial III, pág. 2149. 
Pérez Gordo: «Naturaleza y funciones del Ministerio Fiscal en la Constitución y en su Estatuto Orgánico de 1981», Rev. Jurídica de Cataluña, 1983, II, pág. 65.

Pietro Castro: «El Ministerio Fiscal en Europan, Rev. Derecho Procesal, 1977, pág. 3.

-: «Construcción dogmática del Ministerio Fiscal en el Orden Civil», en Trabajos..., pág. 3.

Rojo Urauntia: «El Fiscal, defensor de los derechos del ciudadano», Bol. del litre. Colegio de Abogados de Madrid, núm. 3, mayo-junio de 1987.

RuIz VADILLO: “La actuación del Ministerio Fiscal en el proceso penal», Rev. Derecho Procesal, 1979, pág. 609.

Vercher Noguera: "¿Hacia un Ministerio Fiscal Inglés?», Rev. La Ley, núm. 1684, martes 7-4-87.

VIADA LoPez-PuigCerver: «La posición del Ministerio Fiscal en el proceso penal», Rev. Jurídica de Cataluña, 1956, pág. 321.

ZAFra: «Posición del Ministerio Fiscal en el futuro proceso penalm, Rev. Derecho Procesal, 1961, pág. 753.

\section{El Defensor del Pueblo}

\section{OBRAS GENERALES}

Almagro Nosete, Cortes Dominguez, Gimeno Sendra y Moreno Catena: Derecho Procesal. Tomo I: Parte General. El proceso civil, pág. 173.

\section{MONOGRAFIAS}

Aguila Fernandez-Montoria: A propósito del Defensor del Pueblo, los rasgos definidores de la posición jurldica de los organos auxiliaros. Madrid 1986.

AlzaGA: La Constitución Española de 1978. Madrid 1978, págs. 351 y ss.

Aparicio, M. A.: Parlamento y Sociedad civil. Cátedra de Derecho Politico, Universidad de Barcelona, 1980.

Aradillas: Todo sobre el Defensor del Pueblo. Plaza y Janés. Barcelona 1985. 
Bar Cendón: «El Defensor del Pueblo en el Ordenamiento Juridico español», en El Desarrollo de la Constitución de 1978. Facultad de Derecho, Universidad de Zaragoza, 1982, pág. 299.

-: "La regulación jurídica de los "Defensores del Pueblo regionales": ¿Cooperación o conflicto?», Rev. de Derecho Politico, 1983, núm. 18, pág. 77.

Bonet Navarro: Procesos ante el Justicia de Aragón, Zaragoza. Guara Edit., 1982, 204 págs.

Canales Aliende: «El Defensor del Pueblo y los pensionistas de la Seguridad Social. Presupuesto y Gasto Públicom, IEF, núm. 7, 1980, págs. 17 y ss.

Cano Bueso: El Defensor del Pueblo andaluz: génesis y contenido de la Institución. Defensor del Pueblo Andaluz. Sevilla 1986.

CARRILlo LOPEZ: “EI Defensor del Pueblo, factor de democratización», Rev. Juridica de Cataluña, núm. 4, 1982.

Dapena Baqueiro: Ley Orgánica del Defensor del Pueblo. Instituto Nacional de Prospectiva. Madrid 1980.

Fairén Guillén: El Defensor del Pueblo. Ombudsman. CEC, 2 vols. Madrid 1982.

-: «Normas y notas sobre el Ombudsman de Suecian, Rev. de Estudios Politicos, mayojunio de 1981.

-: «Actividades recientes de algunos 'Ombudsmännen" (incluido el Defensor del Pueblo)», Rev. Española de Derecho Administrativo. Civitas, núm. 40, abril-junio de 1985, págs. 227-253.

FIX Zamudio, Héctor: La protección juridica y procesal de los Derechos Humanos antes de las jurisdicciones nacionales. Civitas. Madrid 1982, pág. 305.

Folchi, I., y BAyONA, A.: "La defensa de los Derechos Fundamentales y de las Libertades Públicas en el ámbito de las Comunidades Autónomas. Instituciones similares al Defensor del Pueblo», Rev. Vasca de Administración Pública, núm. 6, 1983.

Gallego Muescar, Carlos: «El Defensor del Pueblo: competencias, procedimiento y Derecho Comparado", Rev. de la Facultad de Derecho. Universidad Complutense. Madrid, diciemtre de 1982.

Gamiz Valencia, C.: “El Defensor del Pueblo en España», Rev. Internacional de Ciencias Administrativas, 1981, pág. 349.

Garrido Falla, Fernando: Comentarios a la Constitución. Madrid 1980, págs. 592 y ss.

Gil Robles y GIL DELGADo: El control parlamentario de la Administración: el Ombudsman. INAP. Madrid 1981 (2." edición).

-: El Defensor del Pueblo. Cuadernos Civitas, 1979. 
Gil Robles y GIL Delgado: El Defensor del Pueblo: comentarios en torno a una proposición de Ley Orgánica. Civitas. Madrid 1979.

-: «El Defensor del Pueblo e instituciones similares de ámbito territorial reducido», Rev. de la Facultad de Derecho. Universidad Complutense de Madrid, 1981.

-: “Defensor del Pueblo y Administración de Justicia», Rev. del Consejo General de los llustres Colegios de Procuradores de los Tribunales de España, 1981, núms. $1 .^{\circ}$ y $2 .^{\circ}$

-: «El Ombudsman como medio de control parlamentario de la Administración», Rev. Univers., vol. XXI, núm. 81, Madrid 1972.

-: «El Ombudsman o el control parlamentario de la Administración. Repertorio Bibliográfico», Boletin Informativo de Ciencia Politica, núm. 6, Madrid, abril de 1971.

-: Ponencia y debate en la Mesa redonda sobre el Defensor del Pueblo y la Administración. Edit. por CEC y Dir. General del Orden y Desarrollo Ad. Madrid 1981.

-: «El procurador ante las nuevas Instituciones Constitucionales para la defensa de los derechos de los ciudadanos. VI Congreso Nacional de los procuradores de los Tribunales", Canarias 79 , págs. 103 y ss.

Giner de Grado: Los Ombudsmen europeos. Tibidabo Edicions, S. A., 1986.

-: El Defensor del Pueblo: la teorla y en la práctica. Editorial Popular, S. A., 1986.

GonzAlez-Haba: “La Administración y Función Pública en el Informe Anual del Defensor del Pueblo a las Cortes Generales, 1983", Documentación Administrativa, octubre-diciembre de 1984.

Gonzalez Pérez: «Nuevos sistemas de control de la Administración Pública», Rev. Española de Derecho Administrativo, 22, 1979, págs. 399-428.

Gordillo: La Administración Püblica. El parasistema jurídico-administrativo. Civitas. Madrid 1982.

Guerra-Librero Arroyo: “El Ombudsman, defensor del ciudadano», Rev. de Estudios de la Vida Local, núm. 196, Madrid 1977.

-: «El Ombudsman, protector del Ciudadano y defensor de la equidad», Impuestos de la Hacienda Pública, núm. 365, 1973.

Iguiguren Imaz: «El "Ararteko" o Defensor del Pueblo vasco", Rev. de Estudios Políticos, núms. 46-47, julio-octubre de 1985, págs. 585-607.

LA PÉrgola: “Ombudsman y Defensor del Pueblo. Apuntes para una investigación comparada”, Rev. de Estudios Políticos, Madrid, enero-febrero de 1979, págs. 69-92.

LOPEZ DE HARO: «La Constitución y libertades de Aragón y el Justicia Mayorm. Madrid 1926, 645 págs. 
LuQue SeVILLA: El Defensor del Pueblo andaluz. Delegación Interprovincial del IEAL. Granada 1984.

MesA: Mesa redonda sobre el Defensor del Pueblo. Centro de Estudios Constitucionales, 1980.

Mesa redonda sobre el Defensor del Pueblo y la Administración: el Defensor del Pueblo y la Administración. Centro de Estudios Constitucionales. Madrid 1983 (2." edición).

MONTORo Paieto: "La alternativa Defensor del Pueblo-Ministerio Fiscal en la garantia jurisdiccional de derechos fundamentales y libertades públicas en España», Rev. Internacional de Derecho Administrativo, págs. 48 y ss.

Pellón: «El Defensor del Pueblo. Legislación española, derecho comparado», Col. Informe, núm. 33, Presidencia del Gobierno, 1981.

-: «La metamortosis del Ombudsman», Documentación Administrativa, núm. 161, septiembre-octubre de 1974.

-: «¿Un Ombudsman para España?», Documentación Administrativa, núm. 170, 1976, págs. 99 y ss.

Pérez Calvo: "Defensor del Pueblo y Comisionado Parlamentario Vascon, Rev. Vasca de Administración Pública, núm. 3, 1982, págs. 31-55.

-: «El Defensor del Pueblo: artículo 54», Comentarios a las Leyes Políticas. Oscar Alzaga Villaamil. Tomo IV. Edersa. Madrid 1984, págs. 499-522.

-: «Rasgos esenciales del Defensor del Pueblo según la Constitución y la Ley Orgánica 3/1981, de 6 de abrilı, Rev. de Derecho Polltico, núm. 11, 1981, págs. 67-81.

-: «Aspectos constitucionales del Defensor del Pueblo», Rev. Departamento de Derecho Politico de la UNED, núm. 4, 1979, págs. 79 y ss.

Ramirez: El Control parlamentario del Gobierno en las democracias pluralistas. Labor. Barcelona 1978.

Ramos ILLAN: «Restauración del Palacete de Bermejillo para sede del Defensor del Pueblo», Rev. de Arquitectura y Diseño, núm. 54, 1984.

SAN PIo, Carlos: «El Ombudsman», Boletín Informativo de Ciencia Politica, núm. 6, abril de 1971.

SIMPOSIO SOBRE “EL OMBUDSMAN EN LOS PAISES EN DESARROLLo*, en Revista Internacional de Ciencias Administrativas, vol. 2, 1984.

ULL PONT: «EI Defensor del Pueblo», Lecturas sobre la Constitución Española. Facultad de Derecho de la UNED. Madrid 1978.

Viñas Otero: "Del Tribunus Plebis romano al Defensor del Pueblo", Rev. Jurldica La Ley, tomo 3, 1984, págs. $942-949$. 
Varela Suanzes-Garpegna: “La naturaleza jurídica del Defensor del Pueblo", Rev. Española del Derecho Constitucional. CEC, núm. 8, año 3, mayo-agosto de 1983, págs. 63-80.

VISIEDO MAZON: «EI Defensor del Pueblo: instituciones similares en el ámbito de las Comunidades Autónomas", Congreso Nacional de Ciencia Política (4. ${ }^{\circ}$, Alicante 1984).

\section{Abogados y Procuradores}

\section{OBRAS GENERALES}

Almagro nosete, Cortés Dominguez, Gimeno Sendra y Moreno Catena: Derecho Procesal. Tomo I, págs. 173 y ss., y 306 y ss.

Calamandrel: Instituciones. Tomo II, págs. 387 y ss.

Oliva Santos, de la y Fernández: Derecho Procesal Civil. Tomo I: Introducción. El proceso civil, sus tribunales y sus sujetos. PPU. Barcelona 1988, págs. 367 y ss.

Fenech Navarao: Derecho Procesal Penal. Tomo 1, págs. 371 y ss.

GOMEZ de LIAÑo: El proceso..., págs. 70 y ss.

-: Abogacía y Proceso. Oviedo 1988.

Gomez Orbaneja: Derecho Procesal Civil, pág. 151.

Guasp Delgado: Derecho Procesal Civil. Tomo I, pág. 188.

Lorca Navarrete: Derecho Procesal Orgánico, págs. 133 y ss.

Montero Aroca y Ortells Ramos: Derecho Jurisdiccional. Tomo I, pág. 248.

Morello, Berizonce, HitTers y Nogueira: «Formación profesional y capacidad técnica del abogado", en La Justicia entre dos épocas. LEP. La Plata 1983, págs. 133 y ss.

Prieto-Castro y Feraandiz: Tratado de Derecho Procesal Civil. Tomo I, pág. 348.

-: Derecho Procesal Civil. Tecnos. Madrid 1988, págs. 90 y ss.

-: Derecho de Tribunales. Aranzadi. Pamplona 1986, págs. 517 y ss.

Prieto-Castro, Almagro Nosete y Gonzalez-Deleito: Tribunales españoles..., págs. 99 y ss. 


\section{MONOGRAFIAS}

AvRIL: La responsabilité de l'avocat. Paris 1981.

Bielsa: La abogacía. Buenos Aires 1960.

Boccara: Los honorarios del abogado. Madrid 1984.

Calamandrel: De las buenas relaciones entre los jueces y los abogados en el nuevo Proceso Civil. Buenos Aires 1983.

Carrera Bascunan: El secreto profesional del abogado. Chile 1963.

Conture: Los mandamientos del abogado. Buenos Aires 1966.

FENECH: «El secreto profesional del Abogado», Rev. Jurídica de Cataluña, 1949, pág. 379.

-: «El Abogado de todos», Rev. General de Derecho, 1953, pág. 182.

FERnANDEZ BoIXADER: El Abogado ante el sumario. Madrid 1964.

Fernandez Serrano: De las incompatibilidades para ejercer la abogacia. Madrid 1952.

Gómez de LIANO: «Perfiles de la Abogacia española», Rev. Juridica de Cataluña, 1973, pág. 125.

GuASP: «Actividades de dirección jurídica», AAMN, VI, 1952, pág. 7.

GUTIERREZ-ALVIz y ARMARIO: «La postulación procesal: representación y defensa», en Estudios..., pág. 175.

Hamelin: Les règles de la nouvelle profession d'avocat. Paris 1981.

HERNANDEZ GIL: El Abogado y el razonamiento juridico. Madrid 1975.

Lega: Deontologia de la profesión de Abogado. Madrid 1976.

MARTINEZ VAL: Abogacia y Abogados. Barcelona 1981.

—: $\quad$ EEl abogado ante el juicio oral», RGD, núm. 513, junio 1987.

Montes Olavarrieta: De la prevaricación de Abogados y Procuradores. Chile 1963.

Prieto-Castro: La Jura de cuentas en general y aplicada a profesiones no jurídicas.

-: «El procedimiento privilegiado de exacción de los artículos 7, 8 y 12 de la LEC», en Estudios... Tomo It, págs. 566 y 609. 
Prieto-Castro: La abogacía en el momento presente, 1982.

Rigo Vallbona: El secreto profesional de Abogados y Procuradores en España. Barcelona 1988.

Rodell: iAy de vosotros Abogados! Buenos Aires 1966.

Rodriguez Espejo: «Personalidad del Procurador y sustitución del poder», Rev. Derecho Procesal, 1973, pág. 637.

SerRA: «Obligaciones del Procurador», Rev. Juridica de Cataluña, 1963, pág. 12.

-: «Impugnación de honorarios», en Estudios..., pág. 328.

ZARAGOZA: Los Abogados y la sociedad industrial. Barcelona 1982.

ZULetA y CeBrián: «La postulación procesal», Primeras Jornadas de Derecho Judicial, pág. 769.

\section{Letrados del Estado}

\section{OBRAS GENERALES}

Almagro Nosete, Cortés Dominguez, Gimeno Sendra y Moreno Catena: Derecho Procesal. Tomo I, págs. 175 y ss.

Jiménez Asenjo: Derecho Procesal Penal. Tomo l, págs. 149 y ss.

Lorca Navarrete: Derecho Procesal Orgánico, págs. 216 y ss.

-: Derecho Procesal Penal, págs. 61 y ss.

Montero Aroca y Ortells Ramos: Derecho Jurisdiccional. Tomo I, págs. 347 ss.

Prieto-Castro: Derecho de Tribunales, págs. 509 y ss.

Prieto-Castro, Almagro Nosete y Gonzalez-Deleito: Tribunales españoles..., págs. 97 y ss.

Ramos Méndez: Derecho Procesal Civil. Tomo I, págs. 30, 124 y ss. 
MONOGRAFIAS

Martin-Retortillo Baquer: La defensa en derecho del Estado: aproximación a la historia del cuerpo de Abogados del Estado. Madrid 1986.

Pavone: Lo stato in giudizio: gli Enti pubblici diferi dall'avvocatura dello Stato. Milano 1982.

\section{PRINCIPIOS DEL ORDEN JURISDICCIONAL PENAL}

\section{Derecho a la participación popular}

OBRAS GENERALES

Almagro Nosete: "Acerca del Jurado», en Consideraciones de..., págs. 80 y ss.

Aragoneses Alonso: Instituciones de Derecho Procesal Penal. Madrid 1981, págs. 113 y ss.

—: Curso de Derecho Procesal..., págs. 107 y ss.

Gimeno Sendra, Moreno Catena, Almagro Nosete y Cortes Dominguez: Derecho Procesal. Tomo II: El Proceso Penal. Tirant lo Blanch. Valencia 1988, págs. 42 y ss.

Gómez de Liaño: El Proceso Penal, págs. 58 y ss.

Levene: Manual de Derecho Procesal..., págs. 81 y ss.

MONOGRAFIAS

Alcala-Zamofa y Castillo: “Sobre el Jurado...., en Estudios Diversos de Derecho Procesal, pág. 67.

Alejandre Garcla: La justicia popular en España. Madrid 1981.

ASENCIO MELLADO: «EI Jurado "auténtico", "puro" y "verdadero"”, La Ley, 1987, tomo II, pág. 940. 
De Coco, Ledesma y otros: El Jurado, 1983.

Davo Escriba: El Tribunal del Jurado. Reflexiones acerca de su desarrollo constitucional. Madrid 1988.

FAIREN GUILLEN: “Los Tribunales de Jurados en la Constitución española de 1978». Madrid 1979.

-: «El Jurado», en Estudios..., 1983.

-: «El Jurado: algunos aspectos del mismo», Jornadas de Derecho Procesal, 1984, pág. 231.

-: "De nuevo sobre el Jurado», Rev. Derecho Procesal, 1982, pág. 491.

-: «El Jurado y la Constitución», Rev. La Ley, 1985, tomo II, pág. 1042.

Gimeno SendRA: «El artículo 125 de la constitución de los Tribunales de Jurados y de Escabinos", Rev. General de Legislación y Jurisprudencia, 1981, núm. 4, pág. 343.

-: "La participación popular en la Administración de Justicia», Poder Judicial, 1983, II, pág. 1405.

Gomez Colomer: «Comentario a los artículos 19.2 y 83 de la Ley Orgánica del Poder Judicial de 1985: problemas prácticos aplicativos y de lege ferenda del futuro juicio con Jurados en el proceso penal", Rev. La Ley, 1986, tomo I, pág. 1047.

Gutiérrez-Alviz y Conradi: «La instrucción del Jurado o juez lego», Rev. La Ley, 1987, tomo I, pág. 1115.

hastie, Penrod y Pennington: La institución del Jurado en los Estados Unidos, sus intimidades, Madrid 1986.

HIDALGO TORRES: «EI Jurado: oportunidad y "recencia"», BICAM, núm. 23, marzo-abril de 1987.

Lorca Navarrete: «Hacia un auténtico Jurado», La Ley, tomo IV, pág. 1183, 1986.

LozAno: «El Jurado de Conciencia y el Jurado de Derecho», Derecho Penal y Criminología, núm. 31, enero-abril de 1987.

MARTin Ostos: «Algunas consideraciones sobre el Jurado", Anales de la Facultad de Derecho de Cáceres, núm. 3.

Ortells Ramos: «Eficacia probatoria del sumario en el juicio ante jurado», Justicia 87 , núm. II, pág. 347.

Pedraz Penalva: «Sobre el significado y vigencia del jurado», Justicia 86, núm. IV, pág. 967.

SORIANO: «EI nuevo Jurado españolm, 1985. 
SORIANO: «Hacia un Jurado de escabinos para España», Justicia 85, núm. I, pág. 27.

-: «El Derecho a la Justicia popular: el nuevo jurado español», La Ley, tomo I, pág. 1024, 1985.

-: «Argumentos y líneas programáticas de un jurado de escabinos para España», RDP, núm. 2, 1987.

Varios Autores: «El Jurado», Rev. Vasca de Derecho Procesal. Tomo I, núm. III, 1987.

VEGA RUIZ, DE: «EI Jurado y el Juez ordinario y predeterminado por la Ley», La Ley, núm. 2304, 29-8-89.

\section{El derecho al Juez legal}

Gimeno Sendra, moreno Catena, Almagro nosete y Cortés Dominguez: Derecho Procesal. Tomo II: Proceso Penal, págs. 46 y ss.

Aragoneses: Instituciones de Derecho Procesal Penal, págs. 93 y ss.

ARAgONESA SieRra: “Ponencia sobre Jueces ordinarios y Constitución», Documentación Juridica. Tomo XII, enero-junio de 1985, págs. 3 y ss.

Fairén Guillén: "Comentarios a la Ley Orgánica del Poder Judicial de 1 de julio de 1985", Rev. de Derecho Privado, 1986, pág. 29.

Gomez de LiANo: El proceso penal, págs. 49 y ss.

Gomez Orbaneja y Herce Quemada: Derecho Procesal Penal, págs. 33 y ss.

Lorca Navarrete: Derecho Procesal Penal, págs. 38 y ss.

Montoro: Conflicto social, Derecho y Proceso, pág. 81.

Prieto-Castro: Derecho de Tribunales, págs. 98. 